\title{
AN APPRAISAL OF THE COSTS AND BENEFITS OF GOVERNMENT-REQUIRED DISCLOSURE: SEC AND FTC REQUIREMENTS
}

\author{
George J. Benston* \\ INTRODUCTION
}

Supreme Court Justice Brandeis' metaphoric argument "Sunlight is said to be the best of disinfectants; electric light the most efficient policeman" is regarded by many as a truism. ${ }^{1}$ The Securities Act of 1933 (characterized as a disclosure statute) and the Securities Exchange Act of 1934 are based on this assumption. ${ }^{2}$ President Roosevelt opted for disclosure rather than attempt to establish as federal statute the merit regulation of securities sales that had been enacted in the blue sky laws adopted in about half the states. As he put it in his message to Congress supporting the 1933 Act: ${ }^{3}$

There is, however, an obligation upon us to insist that every issue of new securities to be sold in interstate commerce shall be accompanied by full publicity and information, and that no essentially important element attending the issue shall be concealed from the buying public.

This proposal adds to the ancient rule of caveat emptor, the further doctrine, "Let the seller also beware." It puts the burden of telling the whole truth on the seller. It should give impetus to honest dealing in securities and thereby bring back public confidence.

The 1934 Act, though not explicitly called a disclosure statute, has evolved into the more demanding of the two Acts. As amended, it requires annual disclosure of a large amount of financial data, more limited quarterly statements, monthly reports of "significant" events, proxy information, and so forth. The extent and form of disclosure required has expanded greatly in the past several years to include product-line data, compensating balance arrangements for loans, and most recently the replacement costs of large corporations' fixed assets. There is every reason to believe that more rather than less specific disclosure of data will be required as a consequence of the review of disclosure policies recently completed. ${ }^{4}$

\footnotetext{
* Professor of Accounting and Finance, Graduate School of Management, and Center for Research in Government Policy and Business, University of Rochester.

1. L. Brandeis, Other People’s Money 62 (1933).

2. Securities Act of 1933, 15 U.S.C. $\$ \S 77 \mathrm{a}-77$ aa (1970); Securities Exchange Act of 1934, 15 U.S.C. \$§ 78a-78jj (1970).

3. 77 Cong. Rec. 937 (1933).

4. See Report of the Advisory Comm. on Corporate Disclosure to the Securities and
} 
The disclosure requirements for most corporations (all those with more than 500 shareholders or $\$ 1$ million in assets) are based in large measure on the assumption that investors would be insufficiently served were the laws and regulations not in place and administered by the Securities and Exchange Commission. In brief, the benefits which are assumed to flow from these requirements are: less fraud on investors, better administration of the reporting corporations, more equitable and efficient capital markets, and a more efficient allocation of resources in the economy. In addition, it is claimed that government officials require the data made public by corporations to improve the administration of their offices and their management of the economy.

This latter presumed benefit is one of the major motivating forces behind other enacted and proposed legislation that requires public disclosure by private enterprises. In particular, many regulated industries have long had to report detailed data on their operations to supervisory commissions. Railroads report to the Interstate Commerce Commission, utilities to public service commissions, insurance companies to state agencies, banks to federal and state agencies, etc. There are two predominant reasons for this type of reporting requirement. One is that the companies enjoy a natural or government-created monopoly, and hence their operations, management, revenues, costs, assets, liabilities, and financing must be revealed to the agencies charged with their regulation. The other is that financial institutions, such as banks and insurance companies, are guardians of the public's funds and hence must be scrutinized by the public's servants.

The New Deal promulgated another reason for requiring that private companies report to government. While the public and the government officials generally believed that the "invisible hand" of profit-oriented decisions by business persons and consumers resulted in the optimal allocation of resources (except in natural or government-franchised monopolies), there was little reason for government to gather and use private financial data other than for tax collection. But once this view was replaced with the belief that private enterprise was not working well and that government officials should manage the economy, extensive reporting of data on business and other operations was considered necessary. Furthermore, the concern that the economy was characterized more by oligopolies which administered prices than by competing enterprises led to a demand by government agencies such as the Federal Trade Commission for detailed data on market and industry shipments, sales, advertising, profits, investments, and so forth.

Finally, the recent revelations of corporate misbehavior, particularly with respect to illegal domestic political contributions and questionable overseas payments, have increased demands that the operations of larger corporations

Exchange Commission, printed for the House Comm. on Interstate and Foreign Commerce, 95th Cong., lst Sess. (Comm. Print 1977) [hereinafter cited as REPORT]. 
be subject to greater public scrutiny. ${ }^{5}$ These demands are but continuations of a movement prevalent at least since the 1930's to require private enterprises to disclose their financial and other data to government agencies and to the public.

In light of what appears to be a strong public preference for more rather than less disclosure, it might seem foolish to question whether the costs of required corporate disclosure exceed the benefits. Few people can recall a time when the SEC did not exist, and therefore few may even be able to imagine a situation in which corporations would not have to file S-1's when they sell stock and periodically file 10K's, 10Q's, 8K's, etc. Government officials, such as those who attempt to manage the energy situation, must bemoan the paucity of data that are reported to them, rather than the reverse. The FTC in particular is attempting to implement a massive data collection effort. Its line-of-business report program would require some 440 of the largest manufacturing corporations to report very detailed financial data annually, disaggregated into standard industrial code (SIC) classifications. ${ }^{6}$ While such a data collection program may have been considered overwhelmingly expensive in the past, the development of high-speed computers has made it relatively inexpensive for a government agency to store and process large amounts of data. Thus a past restraint on government data collection no longer exists.

But this is also a time when traditional beliefs are being questioned. Perhaps it is no more ridiculous to ask whether more required financial disclosure is better than less than it is to ask whether a woman's place is always in the home, or whether smoke pouring out of factory chimneys necessarily is a sign of progress and prosperity.

I must emphasize at the outset that my concern is with required financial disclosure. As I demonstrate below, corporations published financial statements long before the SEC existed. We can presume that this disclosure met the cost-benefit criterion, since it was made voluntarily. A corporation could sell shares without disclosing much, and many did so; but others provided information apparently because they believed that the benefits from, say, enhanced interest from investors exceeded the cost to them of preparing and distributing the data and of having their competitors learn about their operations. Audits were conducted by C.P.A.'s, annual reports were voluntarily issued, new developments were announced, and so forth before 1934. The question at issue, then, is not whether disclosure as such is a good thing, but whether the benefits of government-mandated disclosure exceed its costs and

5. See, e.g., Staff of Subcomm. on Oversight and Investigations of House Comm. on Interstate and Foreign Commerce, 94th Cong., 2d Sess., Report on SEC Voluntary Compliance Program on Corporate Disclosure 1-15 (Comm. Print 1976).

6. See Agriculture-Environmental and Consumer Protection Appropriations for 1975: Hearings Before Subcomm. on Agriculture-Environmental and Consumer Protection of the House Comm. on Appropriations, Part 9, 93rd Cong., 2d Sess. 601-51 (1974) [hereinafter cited as Hearings]. 
which persons (e.g., consumers, investors, or government officials) obtain the benefits and assume the costs. To keep the discussion within reasonable bounds, I have limited this paper to the reporting requirements of the SEC and the FTC. Each provides a good example of two aspects of governmentmandated disclosure.

The Costs of Mandated Disclosure

\section{A. The Direct Costs}

\section{SEC Reports}

Not all of the costs of record keeping, auditing, and report preparation are due to mandated disclosure. Corporations keep many records that aid in the management of their enterprises. As was mentioned above, most larger publicly owned corporations were audited by C.P.A.'s before the SEC in effect imposed this requirement. ${ }^{7}$ Furthermore, almost all corporations whose shares were traded on stock exchanges (and hence, until 1964, the only ones subject to the periodic reporting requirements of the Securities Exchange Act of

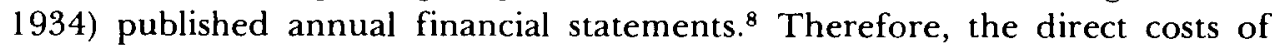
meeting the requirements imposed by laws and government agencies should include only the expenses that otherwise would not have been incurred.

These additional expenses are considerable for several reasons. First, the amount of detailed data required is considerably greater than corporations would have recorded and reported voluntarily. SEC forms, for example, call for information on compensating balances, detailed schedules of asset amounts, accumulated depreciation and expense amounts, pension costs and provisions, location of plants, and other data that probably would not have been published otherwise. A recent example is the current requirement that large companies report the replacement costs of their fixed assets. ${ }^{9}$ Few, if any, corporations have made those estimates. My conversations with a number of comptrollers indicate that the cost of obtaining these data are considerable, even under the SEC's proposed safe-harbor provision, which would limit the liability of the companies for presenting estimates.

Second, some specific reports probably would not be prepared and dis-

7. In 1926, 82 per cent of the companies whose shares were traded on the New York Stock Exchange (NYSE) were audited by C.P.A.'s. By 1934 the percentage had increased to 94 per cent. Benston, The Value of the SEC's Accounting Disclosure Requirements, 44 Accounting Rev. 515, 519 (1969).

8. At least since 1926 all NYSE-traded corporations issued balance sheets and income statements. Id.

9. SEC Accounting Series Release No. 190 (March 23, 1976), 5 FEd. SEC. L. ReP. (CCH)

I 72,212; SEC Accounting Series Release No. 203 (Dec. 9, 1976), 5 Fed. SEC. L. ReP. (CCH) ๆ 72,225 . 
seminated were it not for the SEC's requirements. One example is audited quarterly reports. While many companies voluntarily prepared quarterly reports, it is doubtful that many would incur the expense of having them certified if the SEC did not require auditors to attest to these data in the annual report. Another example is the requirement that annual reports be sent to shareholders with proxy requests and that $10 \mathrm{~K}$ reports be made available to the public. Except for companies whose shares are listed on the major stock exchanges, it also is doubtful that many firms would file monthly or more frequent reports of changes in control, the acquisition or disposition of a significant amount of assets, material legal proceedings, and so forth, as required in form $8 \mathrm{~K}$.

Therefore, the costs to companies not previously subject to the SEC's reporting requirements probably are not trivial. Unfortunately, I know of no studies of the amount of these costs. One gets only occasional newspaper reports of the additional costs incurred by companies newly subject to SEC regulations and of the effort by some smaller companies to reduce their number of shareholders to free themselves from this burden. I have been unable to verify these data.

In general, though, once a corporation has adapted its records to the SEC's requirements, the additional direct cost of filling in the periodic report forms may not be very great, though it may exceed the benefits thereof. However, the relative burden on smaller corporations is most likely much greater and may be quite onerous.

The direct cost of filing a registration statement (such as the S-1) for a securities issue represents a burden that otherwise might not have been incurred, for several reasons. Companies contemplating their first security issue must gather and record a wealth of data, such as detailed descriptions of the business, its development during the past five years, and future activities to be undertaken; information about the directors and promoters over the past five years; audited and certified profit-and-loss, funds, and retainedearnings statements for the past three years; and a summary of earnings for the past five years with a textual analysis thereof. A consequence of these requirements is that prospectuses usually run to fifty or more pages (measuring $7 \frac{1}{2}$ by 9 inches). In addition, when the SEC requires data that are not recorded in a corporation's records, the cost of obtaining the numbers can be considerable. One example is the requirement that companies going public for the first time file three years' profit-and-loss statements certified by an independent auditor, which means that at least three years' inventories have to have been audited. Nonregistered companies which had not employed independent auditors over that time period for that purpose would suffer the cost of delay. It is not sufficient that they simply disclose that past inventories have not been audited. 
The SEC's regulations also require corporations to incur additional auditing, reporting, and printing costs that are higher than for ordinary reporting. An important determinant of these higher costs is the increased legal liability of accountants and others for SEC reports. Independent auditors have been sued successfully for audit failures and reporting errors. Furthermore, it is not unusual for them to be sued when companies go bankrupt or suffer serious reverses. ${ }^{10}$ The cost to them of such suits is not only the monetary awards imposed and the legal cost of defense, but the cost of damage to their reputations as honest, competent professionals. Hence they must take all suits seriously, whether justified or not. Therefore, the independent auditors must conduct a more extensive, more careful audit and check the effect of postaudit, prefiling events when the figures are to be used in an SEC report. The expense of these procedures obviously is reflected in higher audit fees.

Legal costs and printing fees are higher for SEC reports (particularly new-issues filings) than for others because of legal liability, as just discussed. In addition, since corporate managements and directors also are liable for misstatements and errors in the reports, they cannot passively rely on their hired experts. Therefore, an additional cost is the time and effort of management that could be otherwise employed. Since many, if not most, of these costs do not vary with the dollar amount of the securities issue, the reporting burden falls heavily on smaller companies that plan to raise less money with an issue than their larger competitors do.

\section{FTC's Line-of-Business Report Program}

The direct costs of government-mandated disclosure such as the proposed FTC line-of-business (LB) report may be even greater than the costs of reporting to the SEC. Unlike most of the SEC's required reports, the FTC's reports are not consistent with the usual record keeping and reporting system maintained by any business. Because the FTC wants to use the data to determine whether profits earned by industries (originally they were concerned with markets) are "excessive" and to test hypotheses about the relationship of market structure to performance, it requires corporations to aggregate their data into predetermined categories. These categories follow industries defined by standard industrial codes (SIC). For example, FTC category 31.02 consists of SIC's 313 (footwear, except rubber) and 314 (boot and shoe cut stock and findings); the category includes bindings, bows, buckles, heel lifts, laces, soles,

10. Robert Kellogg has found that investments in firms that are sued generally were earning risk-adjusted negative returns before the suits and that discovery of actionable violations of the federal Securities Acts appears to be associated with abnormally poor firm performance. R. Kellogg, An Empirical Study of Disclosure Error Civil Lawsuits Under the Federal Securities Laws (dissertation in progress, University of Rochester). 
house slippers, men's, women's, infants', and babies' footwear, including dress, casual, and work shoes, boots, and sandals. ${ }^{11}$ Revenues, the cost of operating revenue; traceable and nontraceable media advertising, other selling expenses, general administrative expenses, payrolls, depreciation, and assets must be reported for each defined FTC (SIC) code. Unlike the SEC (and the Financial Accounting Standards Board (FASB)) line-of-business regulations, the FTC regulations do not permit respondents to report these data according to the product and production groups that the management ordinarily uses. Consequently, the data processing costs can be very large.

The extent of these costs is in dispute, but we at least have some estimates. In discussing the 1973 version of its current forms, the FTC said that twentyfive companies estimated annual compliance costs that range from $\$ 5,000$ to $\$ 1,800,000$, with a median value of $\$ 56,000 .{ }^{12}$ The FTC staff then used a series of very questionable adjustments to reduce the estimated median cost of complying with the newer, somewhat more simplified report form to $\$ 24,000$ per company. ${ }^{13}$ The initial setup costs of the program were between $\$ 10,000$ and $\$ 20,000$ per firm, according to the FTC's submission to the GAO, which is charged with approving the form. ${ }^{14}$ These figures were based on data submitted by twenty-five companies for the earlier (1973) form. Their estimates range from $\$ 75,000$ to $\$ 2,000,000$, with a mean value of $\$ 548,000$. The FTC reduced this amount to between $\$ 10,000$ and $\$ 20,000$ by another series of questionable adjustments. Though a detailed analysis is not useful here (and may be found elsewhere ${ }^{15}$ ), it may be instructive to point out one particularly dubious procedure followed by the FTC staff. To estimate the effect on costs of reducing some reporting requirements, the staff telephoned six companies and asked someone (not identified) to estimate the percentage by which the company's previous estimate could be reduced if the requirements were changed. The average percentage reduction in cost is reported to be eightytwo per cent. This may seem to be a rather large reduction. In fact, examina-

11. Hearings, supra note 6, at 631; Office of Management and Budget, Standard Industrial Classification Manual 133-34 (1972).

12. 1974 Form LB Revision 7. Bureau of Economics Staff Memorandum (July 1, 1975).

13. The questionable adjustments include the following: (1) use of a median value as a sufficient statistic to describe a range of values between $\$ 50,000$ and $\$ 1,800,000 ;(2)$ arbitrary reduction of the median value by a third; (3) conversion of costs to a cost per line of business when there is no conceptual or empirical relationship between the number of lines and compliance costs; and (4) multiplication of the computed cost per line of business by the estimated number of lines of the average company (a number that was arbitrarily adjusted downward). A detailed analysis of the procedures used may be found in $G$. Benston. The Cost of Complying with a Government Data Collection Program: The FTC's Line-of-Business Report (unpublished paper on file with author, 1977).

14. Cost to Firms of LB Programs, Memorandum from Keith B. Anderson and William F. Long, Economists, Federal Trade Commission, to James M. Folsom, Acting Director, Bureau of Economics (May 8, 1974).

15. Benston, supra note 13 
tion of the underlying data reveals that this average is computed from the following percentage reductions of each of the six companies: $30,73,77,86$, 99, 99. Thus two companies are reported to have said that the proposed changes would reduce their cost of compliance by ninety-nine per cent. It does not seem reasonable (to me, at least) that they could produce the form for only one per cent of their previous estimates because of some not very extensive, or at least not radical, changes in the reporting requirements.

The most recent cost estimates submitted by the FTC are derived from a telephone survey of some officials of 17 companies who had completed the form. The 17 companies were chosen from among the 30 companies with the largest number of manufacturing lines of business making sales of over $\$ 10$ million. In telephone conversations (apparently not detailed studies) conducted in May and June 1977, the company officials estimated compliance costs of between $\$ 2,100$ and $\$ 100,000$, with a mean amount of $\$ 28,640$.

Many of the companies which would be required to submit line-of-business data to the FTC dispute its estimates of the cost of compliance. Of the 440 companies served with demands to complete the forms, some 170 have filed motions to quash. These noncomplying companies have brought suit in federal court to have the program discontinued. The deliberation in the United States District Court for the District of Columbia before Judge Thomas A. Flannery in June 1977 was restricted to the costs of the program. Judge Flannery requested that five corporations submit affidavits detailing the costs they expected. Table I gives the costs listed in those affidavits.

These companies base their much higher estimates on the fact that their present data recording and processing systems are not congruent with the FTC's prescribed definitions of lines of business. Hence they would have to record all of their basic data, rewrite computer programs, and restructure reports to provide the data required by the FTC. Furthermore, they disagree with the Commission's procedure of estimating compliance cost for a company on the assumption that there is a positive, reasonably meaningful relationship between the number of lines of business and compliance cost. In addition to the fact that the available data show no such relationship (the correlation is not significant), ${ }^{16}$ the companies who are suing to stop the program contend that the cost of compliance is due primarily to the amount of divergence between a company's accounting system and the FTC's reporting requirements. The affidavits filed give fairly detailed numbers and descriptions of procedures in support of this contention and of estimates presented.

The FTC counters that the companies are refusing to take advantage of the instructions that permit "well-informed estimates."17 Rather, they say, the

16. See G. Benston, supra note 13 .

17. Affidavit of William F. Long (director of the LB report program), and testimony at evidentiary hearings before the Honorable Thomas A. Flannery, United States District Judge. 
TABLE I

Estimated Costs of Compliance with the FTC Line-of-Business Report Program

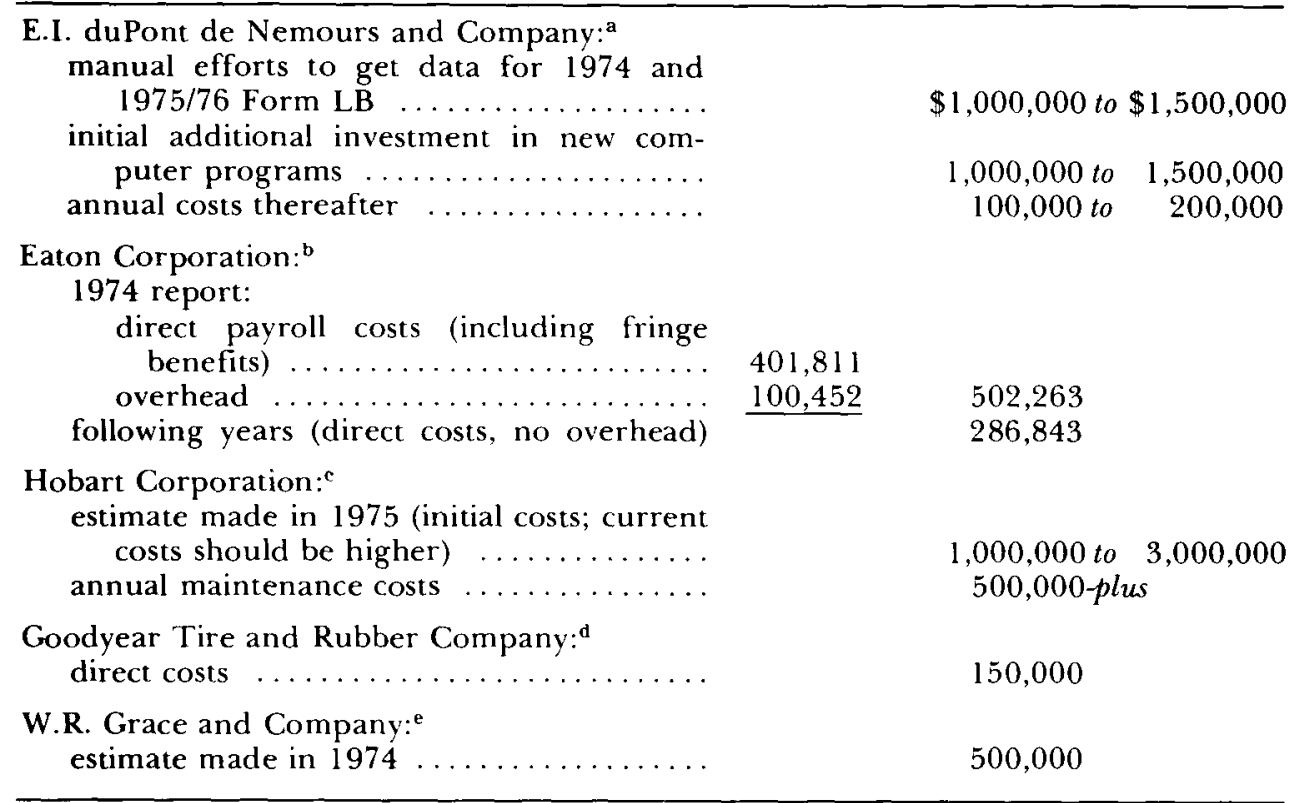

a Affidavit of Howard L. Siers, Assistant Comptroller, filed May 5, 1977.

b Affidavit of F.C. Roberts, Vice President and Controller, filed May 5, 1977.

c Affidavit of Harland L. Mischler, Vice President and Controller, filed May 5, 1977.

d Affidavit of G.A. Sampson, Vice President and Controller, filed May 5, 1977.

- Affidavit of John F. Spellman, Vice President and Controller, filed May 5, 1977. Source: In re FTC Line of Business Report Litigation, 432 F. Supp. 274 (D.D.C. 1977).

companies insist on basing their reports on data that meet the requirements of generally accepted accounting principles (GAAP). Furthermore, the Commission does not ask that the respondents restructure their data processing systems. The companies can provide the demanded data, the Commission claims, primarily by adjusting already existing reports to the requirements of form LB.

However, the companies see themselves in an adversary relationship with the FTC. This view is based on the fact that a primary purpose of the LB report is the gathering of data that will be used to direct antitrust investigations. Though the Commission insists that individual company data will not be used for this purpose, many companies do not believe they can rely on this assurance, considering the FTC's adversary role. In addition, many companies do not believe that the data they report will or can be kept confidential, since

United States District Court for the District of Columbia, June 17, 1977, in re FTC Line of Business Report Litigation, Misc. No. 76-0127 (D.D.C. 1977). 
their file copies are subject to subpoena. Therefore, they may be revealing data that will be useful to competitors or for private lawsuits. Consequently, they cannot be casual or rely on well-informed estimates to report specific numbers.

\section{B. The Indirect Costs}

The major indirect cost of government-mandated reports of accounting data follows from the adversary nature of mandated disclosure. This is the opportunity cost of having data reported that are correct with respect to the regulations but misleading for the purposes of the report's user (type II error). Another opportunity cost is incurred when data that would be useful to users cannot be reported because the government regulations forbid this reporting or because the risk of an adversary action is too great (type I error).

A possible example of the first (type II error) cost is the immediate writeoff of goodwill that the SEC insisted on until recently. ${ }^{18}$ Another possible example is the SEC's insistence (again, until recently) that only historically determined numbers be used, which meant that assets could not be shown at more than their original costs, even where the original costs were demonstrably and significantly less than market values. ${ }^{19}$ (The qualifier "possible" is inserted because it is not known whether these reporting requirements actually misled investors.) The FTC's insistence that companies aggregate their operating data into lines of business that do not reflect markets or other natural groupings of products is another instance of the mandated reporting of potentially misleading data. For example, the FTC may report a high profit rate on sales or assets for the industry (or market) listed as "footwear, except rubber; boot and shoe cut stock and findings ..., ," FTC code 31.02. Assuming that the profit rate reported measures the economic rate of profit (which it most likely does not), the high rate could be due to a very high rate on women's dress shoes that offsets a low rate on men's dress shoes or women's casual shoes, or a multitude of other combinations. If potential entrants to the industry take the numbers seriously, they are very likely to make bad decisions. Similarly, should a shoe manufacturer compare his or her financial results to the numbers the FTC publishes, the manufacturer is likely to be misled.

An example of the second (type I) cost is the SEC's prohibition on the publication of "soft" data, such as the estimated value of natural resources,

18. "There was a period, for example, when the SEC was conducting something in the nature of a campaign to eliminate goodwill from all balance sheets filed with it." L. RAPPAPORT, SEC Accounting Practice and Procedure 7.10 (3d ed. 1972).

19. "I was on the SEC staff at the time [late 1930's], and involved in the decision, when after some years of case-by-case decision, the SEC became firm on the point that historical cost was the required basis of accounting." Kripke, A Search for Meaningful Securities Disclosure Policy, 31 Bus. LAw. 293, 295 (1975). 
patents, or land. ${ }^{20}$ Forecasts, for example, cannot be presented in prospectuses. Until recently, the SEC's adherence to historical-cost-based numbers discouraged, if not prohibited, the presentation of current-market- or pricelevel-adjusted reports.

It is understandable that government-mandated reporting would result in the agencies' requiring adherence to relatively rigid rules or in the respondents' deciding to report only objectively determined data. The agencies have to process a large amount of data. Generally it is not administratively feasible for them to determine whether a company is "correct" (in some sense) when it uses a subjectively derived estimate of value. Hence, the SEC prohibited the use of appraised values for assets, particularly those appraisals of unmined natural resources, such as coal, silver, and oil, that are difficult, if not impossible, to check. ${ }^{21}$ Similarly, the value of intangibles often cannot be measured accurately. Therefore, it is not surprising to find agencies such as the SEC refusing to accept subjectively determined numbers. If they accept such numbers, they run the risk of permitting dishonest managements to publish deliberately misleading data, the cost of which will be borne by the government agency as well as the public. However, where the agency only permits the publication of objectively determined, though not useful, data, neither the agency nor the companies filing the reports are likely to be criticized, particularly when the procedures used have been endorsed by a respected professional body, such as the American Institute of Certified Public Accountants (AICPA) or FASB. Only the public, if they are not fully aware of the data's limitations, will bear the cost.

One consequence of the SEC's past insistence on conservative, historicalcost-based numbers seems to be that some corporations avoid offering debt securities to the public. From 1900 to 1934 , only about three per cent of all corporate debt securities were directly placed, but from 1935 to 1965 forty-six per cent were directly placed. ${ }^{22}$ While there no doubt are many reasons for the change (such as the growth of life insurance companies who tend to invest directly in corporate debt securities), it appears that a major factor was the restrictions imposed by the SEC on information that could be publicized for public security sales. I tested this hypothesis in the following manner. The eight industries for which (since 1953) the SEC publishes data on private and public debt issues were ranked by several professional accountants according to the negative bias imposed by the SEC's accounting rules. (Agreement

20. See Schneider, Nits, Grits, and Soft Information in SEC Filings, 121 U. PA. L. REv. 254-305 (1972). The prohibition is being reconsidered, see text accompanying note 4 supra.

21. See analysis of reasons for adverse decisions on accounting in registrations under the Securities Act of 1933 in Benston, The Effectiveness and Effects of the SEC's Accounting Disclosure Requirements, in Economic Policy and the Regulation of Corporate Securities 23, at 56-58. (H. Manne ed. 1969).

22. A. Cohan, Yielos on Corporate Debt Directly Placed 1 (1967). 
among these professionals was complete.) Rankings then were made of the ratio of debt directly placed to the total amount floated in each year 1953 through 1966 by each industry. Despite the fact that other institutional factors support direct debt placement by some industries (such as railroads) or require the sale of securities by competitive bidding (as is the case with public utilities), the rankings are almost perfectly correlated with direct debt placement-the greater the bias imposed by the SEC, the greater the percentage of debt directly placed. ${ }^{23}$

The factors which motivate agencies such as the FTC to require reporting of essentially useless or potentially misleading data are somewhat different from those that motivate the risk-reducing actions of the SEC. An agency such as the FTC wants information reported in predetermined, uniform aggregates and categories to reduce the cost to them of analyzing data from individual companies. Ease of data handling and mechanical analysis triumph over meaningfulness and accuracy. The alternative probably would require a very large staff that would exceed the FTC's budget and its ability to attract a sufficient number of competent researchers. The consequence of this administrative cost saving is the imposition of the cost of meaningless and potentially misleading data on unwary or careless users.

Thus the direct costs of government-mandated financial reporting borne by corporations (and hence by equity holders, consumers, and taxpayers) include the direct costs of recording, processing, auditing, printing, and reporting the data required. These costs are increased by corporate fear that the data reported may be used to support lawsuits, antitrust litigation, and other adversary actions against them. An additional consequence of this fear is the reporting of data by procedures that are supported by authorities even when the numbers are not reflective of the events they are supposed to reflect. The agencies also tend to want data that are easy and safe to administer. Consequently, the data reported are of limited value to those who would use them as a basis for economic decisions.

Nevertheless, though their value is limited, the data may not be totally useless. I turn, therefore, to a consideration of the benefits that might be derived from the data reported to the SEC and the FTC.

II

The Benefits of Government-Mandated Financial Disclosure

\section{A. SEC-Required Disclosure}

The Federal Securities Acts were passed to correct presumed wrongs and to improve the operations of the securities markets in particular and of the

23. Benston, supra note 21 , at $67-75$. 
economy in general. Seven benefits have been or might be claimed for the corporate disclosure sections of the Acts. ${ }^{24}$ The first four pertain to the fairness of securities investments. Though the concept of fairness is difficult to define operationally, it seems clear that it is a strong reason for the passage and extension of the Acts. The last three benefits are claimed in the belief that the data which corporations could be required to disclose in financial reports are useful for investment decisions. Consequently, the Acts are thought to reduce the cost of investing and improve the allocation of resources in the economy. The following seven benefits are delineated:

(1) Reduction of fraud on investors who might be misled by financial statements that were intended to mislead them;

(2) Reduction or elimination of possibly inadvertent misrepresentation in financial statements that affect investors' allocation of funds;

(3) Reduction or elimination of security price manipulation that is made possible or enhanced by inadequate disclosure of financial information;

(4) Enhanced fairness to noninsiders through the publication of information that otherwise would be available only to insiders;

(5) Greater availability of information that otherwise would not be published, not because managements or insiders would attempt to cheat noninsiders but because the benefits of the information could not be garnered fully by the shareholders of corporations, even though the information would be beneficial to investors in general;

(6) Greater efficiency in making securities investments, as a result of the publication of information that meets known and relatively unambiguous standards of accuracy, reliability, and meaning, that is published in standard format, and that otherwise would not have been available; and

(7) Enhanced public confidence in the securities market because the information disclosed can be trusted, while voluntarily supplied information cannot.

Little, if any, evidence supports the belief that these possible benefits have been achieved. Nor is there much, if any, evidence that is consistent with the claim that the Acts addressed a real problem. Furthermore, reason does not support the belief that the benefits claimed can be achieved or are indeed benefits. Since I have analyzed these (and other) reasons for required disclosure at some length in Corporate Financial Disclosure in the UK and the USA, ${ }^{25}$ the

24. These benefits were delineated by me from readings and conversations. T'o be fair to the proponents of SEC-required disclosure, I tried to err towards specifying more rather than fewer benefits.

25. G. Benston, Corporate Financial Disclosure in the UK and the USA (1976). 
following discussion is not as extensive as it could be. Chapter 4 of that book can be consulted for the references that support the assertions made here. The conceptual bases are discussed first, followed by a review of the evidence.

\section{Conceptual Bases for SEC-Required Disclosure}

a. Fraud, Manipulation, and Unfairness.

The first group of claims-prevention or reduction of fraud, misrepresentation, and other manipulations or unfairness-are derived from two basic assumptions. One is that the financial-statement data would be and can be used to mislead investors; the other is that government regulation of financial disclosure would be effective in preventing this misuse.

It is reasonable to believe that perpetrators of frauds would be willing to use falsified or misleadingly presented financial data to effect their ends. It also seems likely that promoters, managers, and insiders would prefer to hide improprieties or inept performance by preventing disclosure of data that would betray these activities. They also might want to delay or otherwise manage the disclosure of good performance or fortunate occurrences until they were able to secure shares in the enterprise at a less-than-equilibrium price. Thus it seems clear that financial statements might be used in attempts to defraud or mislead investors.

Whether financial statements would have the desired effect is another question. Since it is obvious that improper financial statements may be used to deceive, it also is obvious that investors will rather quickly become aware of the dangers they face in relying on the statements. This is why certified public accountants exist. They are independent experts whose stock-in-trade is an integrity that is rarely compromised. Should they permit their certification of financial statements to be purchased, they risk losing their most valuable asset: their value to clients as certifiers of financial reports. ${ }^{26}$

A second source of protection for the public is the reputation of the investment bankers who market securities. Their role was described well by Arthur Dewing in the 1934 edition of his comprehensive work The Financial Policy of Corporations: ${ }^{27}$

Probably 99 out of 100 prospective investors in the securities of a new company have neither the training, inclination, nor the will to carry on any independent investigation of their own, no matter how much information is put at their disposal. In the last analysis, it is the authority of the investment banker that inspires confidence in the new enterprise and not the investor's reliance on his own powers of analysis. And the investor knows, moreover, that the banker has spent far more time in investigating all the ramifications of the

26. For a more complete exposition see Benston, Accountants' Integrity and Financial Reporting. 43 Financial Executive $10-14$ (1975).

27. A. Dewing, The Financial. Policy of Corporations 1018-19 (3d rev. ed. 1934). 
undertaking than he is likely to spend; and he knows that the banker's reputation is bound up in the success or failure of the undertaking.

Thus there is reason to believe that the security underwriter's and public accountant's reputations would afford investors protection from fraudulent or misleading financial statements in the absence of government disclosure regulations.

However, it can be argued that C.P.A.'s and investment bankers can be compromised by those from whom they receive fees: being human, they may succumb to greed. Government regulation may play a role in requiring the publication of inside dealings and potential conflicts of interest, in ensuring the independence of C.P.A.'s and investment bankers, and in prosecuting those who violate their fiduciary responsibilities.

With respect to the question of fairness, it should be noted that in general, it is not conceptually possible for government disclosure regulations to make security investment fair for all in the sense that all investors have equal access to all information. Even if corporations are required to announce everything to the press, someone must obtain the information first. The chain of transmission includes those who prepared the release, typed it, delivered it, read it before setting it in type, read the galleys, and read the newspaper. Furthermore, some people are more capable of using information than others. Therefore, as is discussed further below, a program of government-mandated disclosure is perhaps more likely to be unfair to shareholders than not. Small shareholders and investors in particular are not likely to benefit, since they probably would not be early in the chain of receivers of the information or have the ability or resources to exploit it efficiently. Whether outright fraud and misrepresentation were a serious problem before passage of the Securities Acts and whether the SEC has eliminated or at least reduced such occurrences are empirical questions that are discussed below.

\section{b. Efficiency of Investment and Allocation of Resources.}

The second group of claims for the benefits of mandated disclosure -improved efficiency of investment and allocation of resources-are derived from the assumption that published financial information is useful for investment decisionmaking. In the case of government-mandated disclosure, this assumption has the following corollaries: (1) the specific disclosures that companies would tend to withhold and the government would require them to disclose are useful; (2) the government (or its delegates, e.g., the FASB) can know which financial numbers are relevant to investment decisions; (3) the disclosures can be sufficiently timely to be of value to the investor.

With respect to the first corollary, it is argued that companies suppress useful information about their operations solely because they cannot restrict 
this information to their shareholders. To understand this argument-and its errors-it is important to note that more information is not always better if it requires resources to produce, distribute, and use. As is true of all goods, there is an optimal quantity that is determined by the cost of the information and its value: the optimal quantity is that amount for which the marginal cost is no greater than the marginal value. Information will be produced by corporations when they have a comparative advantage, when the costs to them are less than the costs to others, ceteris paribus.

If corporations could give their shareholders an exclusive property right in information, they would produce all information which costs the shareholders no more than it benefits them. ${ }^{28}$ This information may even include data about other corporations that would benefit other investors, since the shareholders could sell any information they did not use themselves. In fact, similar reasoning holds in the absence of an exclusive property right in information so long as the shareholders' access to the information is superior to others'. In this situation, the price of the shares will reflect the value to investors of receiving information about the corporation, since receipt of this information will save investors the cost of obtaining it otherwise; hence the shares will be more valuable by the amount saved. The information will still repay the shareholders for the expenses it occasioned on their account, even though their right in it is not absolute.

Nevertheless, the impossibility of granting shareholders an exclusive property right in information does have one effect on the information economy. Corporations who act in their shareholders' interest will not produce and publish information that on balance will benefit other investors at shareholders' expense. Corollary (1) above is based on the argument that this information, which would be withheld in the absence of disclosure requirements, would be of general value if disclosed. But let us see what the value of that information would be.

A requirement that this information be published will harm shareholders, not only by the advantage that the information affords other investors, but also by imposing the cost of the information on shareholders. Sharehold. ers might benefit from required disclosure if there were sufficiently large economies of scale in the production and use of information that are not specific to individual corporations. In this event, the required disclosure by all corporations would provide information that, in total, is of greater value than its cost of production. All investors would benefit, and it is possible that the benefits accruing to the shareholders from information published by other companies would exceed the costs they bear of publishing the informa-

28. For a complete analysis, see F. Milne and R. Watts, Corporate Information: A Public or a Private Good (August 1977) (unpublished manuscript, University of Rochester). 
tion about their own. If sufficient economies of scale do not exist, however, the disclosure requirement will harm shareholders and benefit only other investors.

One counterargument to this is that information is a public good in the sense that its consumption by one person does not reduce its value to another. (Another example is the receipt of a television signal.) But this is true only when prices are in equilibrium. Gonedes, Dopuch, and Penman, for example, say that if the information ${ }^{29}$

provides a completely reliable signal pertaining to the true value of an asset's relative risk ... [it can be used to assess] the equilibrium return on the asset. But the same signal can be used by any other agent who wishes to assess the equilibrium expected return on the asset.

When a share price is out of equilibrium, one person's use of information drives the price towards equilibrium, thereby reducing and ultimately eliminating the value of the information. Hence required disclosure would benefit some persons at the expense of others in this respect as well.

Another argument for the value of required disclosure is that the information disclosed is less costly for investors to use than are voluntarily disclosed numbers. One reason is that the numbers are produced under standards that are known to users. Another reason is that the data are presented in standard formats and are centrally available. This reasoning, however, leads to some questions. What reason is there to believe that C.P.A.-audited data are not reliable and that data produced pursuant to the SEC's historical-cost bias and standards determined by the regulatory rather than the market process are likely to be more useful to investors? And why is it a government function to standardize data or require that corporations produce standardized data?

Finally, the value of disclosed information is affected by the physical problem of transmission described in the previous section. Some shareholders or investors-whoever gets the information first-will trade on it, to the possible detriment of someone who has not yet received it.

Thus if required financial disclosure is useful, it is useful (a) to the investors who receive the information first; (b) only to investors who are not shareholders, unless there are sufficiently great economies of scale in producing the information; or (c) only when the price is out of equilibrium, and then only to some investors. Aside from questions of equity, a determination of whether society as a whole benefits depends on whether the total cost of required disclosure exceeds the total benefits. This determination depends, in part, on whether required disclosure is likely to produce information or simply data, a distinction discussed below.

This brings us to the second corollary listed above, which states that the

29. Gonedes, Dopuch, \& Penman, Disclosure Rules, Information-Production and Capital Market Equilibrium: The Case of Forecast Disclosure Rules, 15 J. Accounting Research 89, 96 (1976). 
government (or its delegates) can know which information is relevant to financial decisions. The theory on which this proposition is based is not as well articulated as one would like. A reasonably good stock-valuation model has yet to be constructed. Economists, accountants, analysts, and others differ considerably on specifically what information is useful for investment decisions. While most people would accept the definition of assets and liabilities as the present value of expected cash flows, it is generally recognized that determination of the relevant cash flows and discount rates is essentially subjective and perhaps impossible. The arguments revolve around which variables and which models are the best proxies for the desired numbers. Therefore, it is questionable whether the employees of the SEC are more likely to determine the relevant data that should be disclosed than are others, particularly those who are investing their own resources. (In this regard, it is useful to note that the SEC has almost consistently opposed cash flow accounting, even though it is consistent with the present-value model, assuming that past cash flows are useful for estimating future cash flows. $)^{30}$

Finally, let us consider the third corollary listed above: If the numbers produced are not distributed to investors with sufficient dispatch, their information content may be learned from other sources. Hence the numbers disclosed will be data, not information, since their receipt will not affect people's expectations. While this essentially is an unresolved empirical question, it seems clear that numbers produced pursuant to government regulations that make the issuer liable to penalties should the reports violate the regulations are likely to be less timely than numbers produced voluntarily. In fact, the SEC has consistently opted for accuracy and conformance with regulations over speed of transmission, particularly with respect to security registration statements.

Though, in my opinion, the weight of the theory does not support the belief that required disclosure is likely to result in benefits gross of costs, the empirical evidence should be considered. The evidence relevant to each of the seven presumed benefits is discussed in turn.

\section{The Evidence on SEC-Required Disclosure}

\section{a. Fraud in Financial Statements}

There is almost no evidence to support the assertion that the financial statements of publicly traded companies were fraudulently or misleadingly prepared in the years prior to the passage of the Securities Acts. ${ }^{31}$ The U.S. Senate hearings that preceded passage of the 1934 Act cite only a few in-

30. SEC Accounting Series Rel. No. 142 (Mar. 15, 1973), 5 Fed. SEC. L. ReP. (CCH) I 72,164.

31. See G. Benston, supra note $25, \S 4.2 .2$ for references. 
stances of fraudulent financial statements. ${ }^{32}$ There were very few cases before 1934 that charged accountants or companies with fraudulent or grossly negligent financial statements. ${ }^{33}$ This lack of cases, however, may have been due to the difficulty of suing certified public accountants because of the prevailing rule of privity. This rule maintained that only the person for whom the statements were directly prepared (usually the company) could sue, unless the auditor had made a reckless misstatement or insincere expression of opinion. The Securities Acts altered that situation, making it incumbent on the accountant to demonstrate that he was free from negligence or fraud inasmuch as, after reasonable investigation, he believed the statements certified were true. Nevertheless, there were few actions against accountants until the 1960's, which is consistent with the belief that there was no pent-up desire to sue public accountants that was suppressed by the difficulty of maintaining a suit.

There is evidence that many prospectuses contained little financial data before passage of the Securities Act of 1933. Though I do not know of a study of the facts, the literature is replete with assertions to this effect. ${ }^{34}$ Other than self-evidently outrageous puffery that implied a promise of great wealth, I know of no evidence of fraudulent financial data in prospectuses. It seems likely, however, that some fraud must have occurred.

However, it also is clear that fraud in financial statements has not been eliminated as a consequence of the Securities Acts. Indeed, such instances as Equity Funding, ${ }^{35}$ Homestake Investment,${ }^{36}$ Yale Express, ${ }^{37}$ H. L. Green,${ }^{38}$ and $\mathrm{Na}$ tional Student Marketing ${ }^{39}$ eclipse the cases of the pre-SEC period. From current evidence, it almost seems as if it is now easier to defraud some investors, possibly because the existence of the SEC lulls them into believing that fraud is a problem of the past.

\section{b. Misrepresentation in Financial Statements}

Misrepresentation-reporting the results of income and operations, assets and liabilities, so as to hide or obscure bad performance or give the illusion of good performance-is thought by many to be a more serious problem than fraud. The misrepresentation may be accomplished by choosing among alternative acceptable accounting procedures (e.g., using the pooling rather than

32. See Senate Comm. on Banking and Currency, Stock Exchange Practices, S. Rep. No.

1455, 73d Cong., 2d Sess. (1934).

33. See, e.g., Ultramares Corp. v. Touche, Niven \& Co., 255 N.Y. 170, 174 N.E. 441 (1931).

34. See, e.g. Friend, The SEC and the Economic Performance of Securities Markets, in Economic

Policy and the Regulation of Corporate Securities (H. Manne ed. 1969).

35. In re Equity Funding Corp. of Am. Sec. Litigation, 416 F. Supp. 161 (C.D. Cal. 1976).

36. Geo. H. McFadden \& Bros. v. Home-Stake Production Co., 295 F. Supp. 587 (N.D. Okla. 1968).

37. Fischer v. Kletz, 266 F. Supp. 180 (S.D.N.Y. 1967).

38. H.L. Green Co. v. Childree, 185 F. Supp. 95 (S.D.N.Y. 1960).

39. SEC v. Nat'l Student Marketing Corp., 402 F. Supp. 641 (D.D.C. 1975). 
purchase method to account for an acquisition), by changing accounting methods (e.g., shifting from first-in-first-out (FIFO) to last-in-first-out (LIFO) inventory accounting), by recording revenue or expenses when convenient (e.g., choosing which asset to sell when similar assets were recorded at different historical costs or capitalizing rather than expensing research and development costs), or by deciding which figure to report as earnings per share (e.g., charging extraordinary expenses to retained earnings or not clearly disclosing the number of common shares that might be issued pursuant to options). Government control over the alternatives that can be used by a corporation for reporting its financial situation is said to be a means of reducing the extent to which such manipulations can occur.

First, the available evidence does not support the claim that manipulations of reported accounting data are successful in fooling investors. ${ }^{40}$ Numerous studies have been conducted that attempt to measure the effect on stock prices of changes in earnings per share that result from changes in accounting procedures. Among the changes studied are shifts from FIFO to LIFO inventory accounting, from accelerated to straight-line depreciation, from statutory to GAAP-determined earnings of life insurance companies, and from historical to price-level-adjusted earnings. Other studies have measured the effect on share price of one method of accounting rather than another. These studies include flow-through versus deferral accounting for income taxes where tax and book depreciation differ, pooling versus purchase accounting for acquisitions, and full-cost versus writeoff accounting of oil and gas exploration costs. The findings of these studies are not consistent with the belief that share prices are affected by differences in accounting procedures alone. Hence, while a requirement that one method or another be used by most companies in an industry might result in less criticism of regulators and accountants, the evidence indicates that it would not benefit investors.

To the contrary, if published accounting statements provide investors with information, a movement towards uniform accounting is likely to reduce the value of that information. This would occur when a particular accounting procedure that provides a meaningful measurement for one firm produces a misleading measurement for another. For example, whether straight-line or accelerated depreciation describes the decline in present value of an asset depends on the pattern of its expected net cash flows. Another example is the requirement that research and development expenses be written off. The correctness of this procedure depends on the expected economic life of the research output. Since regulatory agencies (and accountants fearful of lawsuits) prefer to minimize risk and criticism should the future turn out to be worse than expected, they tend to require conservative, uniform procedures that are likely to result in the publication of misleading financial statements.

40. See G. Benston, supra note $25, \S 4.2 .3$ for citations. 


\section{c. Security Price Manipulation}

It is alleged by the SEC that security price manipulation in the late 1920's and early 1930 's ${ }^{41}$

resulted in a situation in which no one could be sure that market prices for securities bore any reasonable relation to intrinsic values or reflected the impersonal forces of supply and demand . . . . One of the principal contributing factors to the success of the manipulator was the inability of investors and their advisors to obtain reliable financial and other information upon which to evaluate securities.

The SEC refers to the manipulation of the shares of over one hundred companies listed on the New York Stock Exchange. I obtained the names of these companies. ${ }^{42}$ All had financial statements published in Moody's Investors Service for at least two years before their securities were allegedly manipulated. All provided investors with balance sheets and income statements that were audited by C.P.A.'s. The only major items not reported were sales and cost of goods sold. However, the percentage of companies which did not publish these data (in 1929, for example, thirty-nine per cent did not reveal sales and fifty per cent did not disclose cost of goods sold) was smaller in this group than among other NYSE-listed companies whose stock presumably was not manipulated. Thus periodic financial disclosure seems to have had little to do with stock price manipulation.

\section{d. Fairness to Noninsiders}

An operational definition of fairness to a noninsider might be that when he purchases or sells shares, the price paid or received should impound all of the information known to insiders about the company. Thus the price would reflect the intrinsic value of the company, in the sense that while it might not be correct in the light of subsequent events, the probability that this error will be in the investor's favor is equal to the probability that it will be to his loss. Thus the market would be a fair game for the noninside investor.

Of course it is not possible to measure whether the market price of shares reflects all the information that anyone knows about a corporation. In addition, it is not physically possible for all investors to receive all information simultaneously and evaluate it with equal effectiveness. However, it has been shown that if all known information were impounded in share prices, successive price changes would be independent, appearing to follow a random

41. Securities and Exchange Commission, A 25-Year Summary of the Activities of the Securities and Exchange Commission xi-xvi (1959).

42. Benston, Required Disclosure and the Stock Market: An Evaluation of the Securities Exchange Act of 1934, 63 Am. Econ. Rev. 132, 136 (Mar. 1973). See also Friend \& Westerfield, Required Disclosure and the Stock Market: Comment, 65 Am. EcoN. Rev. 467 (1975); Benston, Required Disclosure and the Stock Market: Rejoinder, 65 AM. Econ. Rev. 473 (1973). 
walk. ${ }^{43}$ Thus one can measure fairness by the statistical properties of past share prices; for if the changes were independent, the data would be consistent with the hypothesis that the market was a fair game. (However, this test would not prove the hypothesis.)

Numerous studies of United States share price behavior have been conducted with share price data before and after passage of the Securities Acts, with prices of shares traded on registered exchanges and over the counter, and with daily, weekly, and monthly changes. European stock market data have also been studied. Almost all of these studies report that share price changes are independently distributed. These data indicate, at least, that the Securities Acts have had no measurable effect on the independence of successive share price changes, and that the market was and is in this sense a fair game without this type of legislation.

Nevertheless, it seems likely that there is and was some unfair trading by insiders. Someone must get information before someone else, and the first person is likely to attempt to benefit from his knowledge. However, there is no evidence of which I am aware that shows that the extent of fairness to noninsiders was a serious problem before the Securities Acts were enacted or is any different as a consequence of the financial-disclosure provisions of the legislation.

\section{e. Availability of Information That Otherwise Would Not Be Published}

A primary benefit that the Securities Acts are presumed to achieve is the availability to investors of information that enables them to make informed decisions. Granting that information is beneficial for investment decisions, the efficacy of SEC-required disclosure (gross of costs) is based on the following assumptions, as stated in the discussion of the concepts involved: that the information produced would not have been otherwise forthcoming, and that it is indeed information.

There is some empirical evidence that speaks to the assumptions. First, as is indicated above, a considerable amount of financial data were published before passage of the Securities Acts. Most corporations whose shares were traded on the major exchanges produced the standard audited financial statements. $^{44}$ Though it is said that prospectuses accompanying new securities issues did not provide much information, no study of the extent or adequacy of the information presented has been made, to my knowledge.

Second, there is evidence that the numbers produced pursuant to the SEC's regulations are not information. The major financial item that was not disclosed by a significant number of corporations prior to passage of the 1934

43. See G. Benston, supra note $25, \S 4.2 .5$ for citation to works referred to in this section.

44. See id. $\S 4.2 .6$ for citations to works referred to but not footnoted in this section. 
Act is sales. Thirty-eight per cent of the NYSE-listed corporations did not disclose this number. A statistical test of the meaningfulness of the required disclosure of sales was made by analyzing the behavior of share prices of the corporations that formally disclosed this number for the first time. ${ }^{45}$ I hypothesized that if the required disclosure of sales provided investors with information, the share prices of the affected corporations would differ significantly from the predisclosure magnitudes and variances, with other factors that affect share prices accounted for. The share price behavior of other corporations (sixty-two per cent) that had disclosed sales before 1934 served as a control sample. The statistics showed no significant difference between the pre- and post-SEC period or between the samples that did and did not disclose sales prior to the SEC disclosure requirement. Thus investors appear either to have learned about sales from other sources or to have found the numbers of no measurable (or at least measured) value.

Another test of the market's reaction to SEC-mandated disclosure was conducted by Daniel W. Collins, who was concerned with the post-1970 SEC requirement that corporations publish data by product line. ${ }^{46}$ Since the SEC required that these data be published for prior years, Collins was able to calculate the value of the retrospective data had they been available to investors. For this purpose, he developed and tested share pricing strategies that depend on knowledge of product-line data and compared these to strategies using consolidated data only. Collins found that investors would have made significantly greater returns before commissions, etc., in 1968 and 1969 but not in 1970 had they had this information. Horwitz and Kolodny also examined the usefulness of required product-line disclosure by examining its effect on the share prices and market measures-of-risk of companies who reported segment-income data for the first time in 1971, using a sample of companies that did not as a control. They conclude, "[Our] results provide no evidence in support of the universally accepted contention that the SEC required disclosure furnished investors with valuable information." 47

Finally, there is evidence that by the time financial reports are released to the public, their information content is known. Numerous studies have shown that the publication of annual statements is not accompanied by significant share price changes, which indicates that the data contained therein were known and previously discounted, that the statements do not contain information, or that the research was faulty. ${ }^{48}$ Since other research indicates a greater volume of trading in the period when earnings results are announced, it

45. Benston, supra note 42.

46. Collins, SEC Product-Line Reporting and Market Efficiency, 2 J. Financial Econ. 125 (1975).

47. Horwitz and Kolodny, Line of Business Reporting and Security Prices: An Analysis of an SEC Disclosure Rule, 8 BeLL J. OF ECon. 234, 237 (1977).

48. See G. Benston, supra note $25, \S 4.2 .6$ for references. 
would seem that the financial statements are not totally ignored. ${ }^{49}$ This somewhat conflicting finding was replicated in a recent, as yet unpublished study that speaks directly to the question of the effect of SEC-mandated disclosure. Paul Griffin studied the impact of 1975-76 sensitive-foreignpayments disclosures. ${ }^{50}$ He found a significant increase in transactions in the weeks before and after foreign-payments disclosure. The value of the corporations' shares, though, showed but a small temporary decline: prices reverted to their normal levels within two weeks.

\section{f. Efficiency in Security Investment and in the Allocation of Resources}

There is little direct evidence on the effect of required disclosure on the efficiency with which securities markets operate. I do not know of any measurements of the cost of securities analysis and choice that permits a comparison of the pre- and post-SEC periods. Nevertheless, it is generally believed that the SEC's prospectus regulations result in considerably higher costs than had previously been incurred. Not only are auditing, legal, and printing costs higher, but also the delay that underwriters and corporations must endure while waiting for clearance by the SEC can be very costly. It may be that investors benefit from these expenditures by getting better information that enables them to make more effective decisions. However, even friendly critics of the SEC demur; for example, Homer Kripke says: ${ }^{51}$

I have reluctantly come to the conclusion that the Securities Act of 1933 is not operating as it should and that the prospectus has become a routine, meaningless document which does not serve its purpose. Trying to keep from going entirely academic on the ivory shelf by maintaining my contacts with the practicing bar, I have reached the conclusion that most lawyers agree with me, and think of the registration process as simply a useless, but lucrative bit of paperwork.

It would seem that the costs outweigh the benefits.

Indirect evidence also may be brought to bear on this question. First, as discussed above, the findings that share price changes were independently distributed before the Securities Acts and in countries that do not regulate disclosure as does the United States are consistent with the hypothesis that government-mandated disclosure is irrelevant to the efficient impounding of information within share prices. Other evidence on the immediate effect of SEC-mandated disclosure is also generally consistent with this conclusion. Second, the specific financial information currently published by such financial services as Moody's Manuals and Standard and Poors has changed very little

49. Id.

50. P. Griffin, Disclosure Policy and the Securities Market: The Impact of the 1975-76 Sensitive Foreign Payment Disclosures (November 1976) (unpublished manuscript, Stanford University, Graduate School of Business).

51. Kripke, The Myth of the Informed Layman, 28 Bus. LAw. 631 (1973). 
from that published before 1934. If investors wanted the data that are made available in the $10 \mathrm{~K}$ 's, one would expect these services to provide them. Also, few shareholders have requested 10K's, even when they have been offered at no charge..$^{2}$

It is difficult to determine whether the Securities Acts have enhanced or hindered the efficient allocation of resources in the economy. I do not believe that a detailed study is required to show that investors still make investment decisions that turn out to be disastrous. Sudden and long-run stock market declines have characterized the post-SEC period as least as much as the preSEC years. If anything, it would appear that the higher costs of floating new securities, particularly for small companies, may have hindered the efficient allocation of resources in the economy. Even if some shareholders have been saved from making bad investments, others have been prevented from making good ones.

\section{g. Public Confidence in the Securities Market}

The evidence on this presumed benefit also is mostly indirect. The amount of new securities issues in proportion to capital formation was much lower after the Securities Acts were enacted than before. ${ }^{53}$ The use of private placements instead of public sales of securities also increased dramatically after 1933. The post-SEC period is also characterized by the growing importance of mutual funds and other institutional investors. This evidence is inconsistent with the belief that the Securities Acts enhanced public confidence in the securities markets.

Additionally, it is not clear why greater individual investment in equity securities is a good thing. As recent experience once more shows, equity investments entail risk. Many people might be better advised to invest their savings through financial intermediaries. Why, then, is it a government function to support a particular form of saving?

\section{B. The FTC's Line-of-Business Report Program ${ }^{\mathbf{4}}$}

The FTC claims that the data collected pursuant to its LB program will yield benefits to government, economists, business, labor, investors, and consumers. The specific benefits expected are said to include the following, gleaned from the statements of purpose produced by the FTC: $:^{55}$

52. Shareholders Exhibit Lack of Interest in 10-K Data, $138 \mathrm{~J}$. AcCounTancy 21 (Nov. 1974).

53. See G. Benston, supra note $25, \S 4.2 .8$ for citations to works referred to.

54. For a more detailed analysis see Benston, The Federal Trade Commission's Line of Business Program: A Benefit-Cost Analysis, in Government Informational Needs and Business DiscloSURE (H. Goldschmid ed. in press 1978).

55. These are from the Federal Trade Commission, Annual line of Business Report Statement of Purpose (1973); Bureau of Economics Staff Report, federal Trade Commission Line of Business Reporting Program (1974); and Federal Trade Commission, Supporting Statement, FTC Form LB 1974 Survey Version (1975). 
(1) The government's antitrust enforcement activities will be more efficient, since the LB rate-of-profit and other data will provide improved guides for investigations.

(2) Macroeconomic policy will be supported by the improved quality of data used in the government's efforts to control inflation and unemployment.

(3) Resources will be allocated more efficiently because investors will get data that will point out the industries in which demand is inadequately satisfied and, as a consequence, profits will be particularly high. Stock analysts and investors will also learn more about the performance of individual corporations; this will in turn force managers to use the resources at their command more efficiently.

(4) Economic studies of industry performance will be improved considerably, particularly those that seek to measure the interrelationship among market structure, research and development costs, marketing expenditures, and profits.

(5) Business will benefit by having data that can be used to evaluate performance and pinpoint new opportunities at low cost. Buyers will be able to use the LB data to form judgments concerning the appropriateness of price/cost margins and profit rates.

(6) Labor will benefit because the LB data will facilitate comparisons among industries of labor's share of the pie.

(7) Investment analysts and investors will be able to use the LB reports to evaluate the prospects for particular industries.

(8) Consumers will benefit from the improvement in the markets for goods, services, and capital.

These expectations are based on three key assumptions. First, the LB categories defined by the FTC are presumed to be meaningful aggregates for the purposes delineated above. Second, the data collected are presumed to provide economically meaningful measures of profits per dollar of sales and assets. The third assumption, similar to the SEC's, is that the data that would be collected are not otherwise available to the market. Since the FTC, at the suggestion of the court of appeals, has postponed the compliance deadline at least until March 1, 1978, (to give the court time to consider the case), the analysis must be limited to a consideration of the conceptual basis for the program. ${ }^{56}$ However, in this instance this analysis should be sufficient.

\section{LB Categories and the Definition of Markets}

Most of the benefits claimed for the LB report program depend on the data's being aggregated into meaningfully defined markets. For example, the

56. In re FTC Line of Business Report Litigation, 432 F. Supp. 274 (D.D.C. 1977). 
antitrust laws refer to illegal collusion among producers of a specific product or group of products. Investment decisions similarly require data on markets-groups of products that are substitutes in use. Economic studies and, to some extent, macroeconomics intelligence may use industry rather than market data for some purposes, but the industries defined should include only goods that are substitutes in production. Furthermore, for the data to be useful for purchasing agents, labor leaders, or businesspersons, the numbers should relate to the specific products with which they are concerned. If the LB categories are broad aggregates of products, potential users will not be able to determine the source of a high or low rate of return.

When one examines the FTC-defined categories which are based on standard industrial codes, it is clear that the aggregates cannot be useful for any of the purposes delineated. First, the SIC categories were designed primarily to reflect production rather than consumption groupings. Thus copper roof gutters are in one category and plastic gutters are in another. That is why Betty Bock, Director of Antitrust Research for the Conference Board, says: “[A] detailed analysis of the LB categories made up of single 4-digit SIC codes would be likely to show that few, if any, could be directly correlated with markets whose boundaries are not open to serious debate." 57 Since half of the FTC's codes are even broader (being aggregates of SIC four-digit codes), she concludes: ${ }^{5}$

I have come to believe that published data for the $\mathrm{LB}$ categories could cause the Commission and all other users to make errors so serious that, if the Commission were to proceed with the program, such users would be well advised to behave as if the data did not exist.

Second, the categories are too broad to be useful for most of the delineated purposes. For example, consider one of the more meaningful categories, FTC code 20.07 , frozen specialties. Say an antitrust agency official believes that the market for frozen waffles is monopolized, or a potential manufacturer considers entering the field, or an investor or manager wants to compare the performance of his company with the industry. How can the relevant information be determined when FTC code 20.07 includes data from other frozen products such as baked foods, dinners, pies, pizza, soups, and spaghetti and meat balls? A high (or low) rate of profit for FTC code 20.07 may be due to a high (or low) rate on some of these products combined with a low (or high) profit rate on frozen waffles.

Third, the FTC categories, defined as they are, are contaminated. Because corporations do not keep their records according to FTC codes, they must group the data. To reduce somewhat the otherwise very high reporting bur-

57. Affidavit of Betty Bock with Respect to Proposed 1974 FTC Form LB Before Federal Trade Commission, Statement in Behalf of Aluminum Co. of America, et al. 8 (May 15, 1975).

58. Id. at $9-10$. 
den, the FTC permits respondents to combine data derived from given cost or profit centers (or other established units) that belong in different FTC codes, and report all the numbers as if they were due to a single FTC code if revenue properly belonging to that code is at least 85 per cent of the total. The costs related to the buried FTC codes can be any percentage of the total. An analysis by Dr. Bock indicates that over one-quarter of the FTC categories are likely to be contaminated with respect to revenues (overstated, understated, or both) by more than 15 per cent, and almost half by more than 10 per cent. ${ }^{59}$ No one (including the FTC) will be able to estimate the degree of cost contamination from the data reported. In addition, FTC rules that permit vertically integrated companies to combine data from several FTC codes additionally contaminate the reported categories and eliminate reporting of the categories thus combined. Therefore, even if the FTC defines meaningful aggregates, the data reported would not reflect what they purport to reflect.

\section{The Meaningfulness of LB Data}

Assuming that an FTC line-of-business category represents some meaningful aggregation of data, such as a market, we must next consider whether the data reported represent meaningful measures of profits and rates of return. Most of the benefits expected from the program depend on these measurements. Unfortunately, it is doubtful that this requirement is met because of unsolved and essentially unsolvable problems of intracompany transfers, allocations of common and joint expenses and assets, and the general lack of coherence between accounting numbers and economic values.

\section{a. Intracompany Transfers}

Intracompany transfers are a problem because many, perhaps most, companies do not price them at market prices. For a variety of reasons (control, nonavailability of data, cost-center rather than profit-center organization, tradition, etc.) they use other values, such as actual or standard direct or total cost, and negotiated prices. The FTC recognizes the effect of these practices in its 1973 Statement of Purpose, as follows: "Given the needs of the FTC, it appears that the use of market prices is appropriate. The use of any alternative procedure would distort the measurement of relative profitability." 60 They illustrate how a 10 per cent difference between market and nonmarket transfer prices can distort a rate of return on sales or assets by 21 to 30 per cent. Nevertheless, the FTC permits companies to use whatever method they

59. Bock, Line of Business Reporting: A Quest for a Snark?, 12 Conference BoARd ReC. 10, 18 (Nov. 1975).

60. Federal Trade Commission, Annual line of Business Report Program, Statement of Purpose 11 (1973). 
choose when reporting transfer prices, because they learned that the companies could convert their data to market prices only at a very high cost, if at all. Thus the reported data will be distorted by unknown amounts.

\section{b. Allocations of Joint and Common Cost}

Even more of a problem than transfers, these allocations are particularly troublesome for the corporations that are the subjects of the FTC's program, since an important reason for the existence of multiproduct companies is the efficiency of joint and common production and distribution. That is why multiproduct companies are not just simple aggregates of single-product companies, as are mutual funds or holding companies. Many (perhaps most) companies do not allocate to operating divisions such expenses as central office operation, research and development, and marketing and warehousing. Many more do not allocate divisional expenses to product lines (as the companies define them) or to products. The procedures for making many of these allocations are necessarily arbitrary, since there is no conceptually correct way to allocate a cost to an individual activity if the cost is jointly determined by several activities. Where costs are common to several activities, there usually is no practical way to determine the amounts that would have resulted had only one of the activities been undertaken. Without this knowledge, allocations are not useful for most economic decisions and are likely to provide misleading data. The problem is particularly serious for the FTC line-ofbusiness report, because almost no company is organized according to the FTC's line-of-business categories. Hence the amount of expenses and assets that must be allocated arbitrarily can be considerable.

The FTC recognizes the problem but nevertheless insists that all expenses (other than interest and income taxes) and all assets be assigned and allocated to one or another designated line of business. The magnitude of the distortions due to arbitrary allocations can be estimated from data presented in a study by Mautz and Skousen. ${ }^{61}$ In their survey of 255 companies, they find the average ratio of noninventoried common costs to sales is .078 , while the average ratio of net income to sales is .063 . Thus differences in allocating these costs can have a considerable effect on reported net profits. The magnitudes of these effects can be determined from Mautz and Skousen's analysis of the effect of alternative acceptable methods of allocating common costs on the product-line net profits of 6 companies. A comparison of the net profits per line that a company would report by using its preferred method (designated $P^{*}$ ) compared to the net profits it would report using an alternative (designated $P$ ) was made by expressing $P / P^{*}$ in percentage terms. This cal-

61. Mautz and Skousen, Common Cost Allocation in Diversified Companies, 36 Financial ExecuTIVE 15-17, 19-25 (June 1968). 
culation was made for a total of 30 lines of business on which the 6 companies reported. In one case, the alternative method reported net profits that were only 3 per cent of the profits reported by the preferred method; in another, the alternative yielded 843 per cent of the preferred-method profits. Between those two extremes, the other ratios were scattered as follows: 2 others fell below 5 per cent, 4 fell between 6 per cent and 10 per cent, 9 between 11 per cent and 20 per cent, 4 between 21 per cent and 40 per cent, 2 between 41 per cent and 60 per cent, 1 between 61 per cent and 80 per cent, and 6 in addition to the high of 843 per cent were over 140 per cent. ${ }^{62}$ Thus the method of cost allocation can exert a great influence on the net profits reported. The effect of different allocation methods is likely to be even greater for the FTC data, since they specify many more lines and since their categories do not generally conform to the lines determined by the companies. Furthermore, alternative methods for allocating assets may (and will) be employed. As a consequence, the variance in the profit rate on assets (a key number) will be even greater.

c. The Lack of Coherence Between Accounting Numbers and Economic Values

Expenses should reflect the opportunity costs of earning the revenue reported. Assets should be valued at the cost of replacing their productive potential. As is well known, accounting numbers often provide poor measures of these values. Therefore, unless the magnitudes of the divergence between economic values and the numbers reported is relatively small or can be adjusted, the LB figures will be misleading or meaningless for the purposes of the program.

Two of the variables on which the FTC apparently intends to concentrate, advertising and research and development, are particularly affected by accounting. Accountants charge virtually all expenditures on these items (and other expenditures for intangibles) to current expenses, even though they recognize that many of the expenditures have future value, i.e., are assets. Therefore, companies who once engaged in large amounts of advertising and research that presently are generating sales and profits will report misleadingly high rates of return on assets. Another source of divergence between economic values and accounting numbers is the historical-cost method that, until recently, the SEC insisted upon. Clearly, the practice of not adjusting assets and liabilities for changes in the purchasing power of the dollar and for changes in supply and demand distorts many figures. For example, older companies that purchased fixed assets in the past will show lower-valued assets, lower depreciation, and hence higher profits and higher rates of return

62. See Benston, supra note 54 , at Table 7 for details. 
on assets than will newer companies, ceteris paribus. Consider also the case of a mining company which purchased coal property many years ago. With the greatly increased demand for coal, it will show a high rate of profit, since its depletion charge is based on the original cost of the mine. The profit, though, is due primarily to the company's having purchased the mine at what turned out to be an advantageous time. Antitrust law enforcement officials and potential entrants would not be able to distinguish a profit made from monopoly or monopsony practice from one due to a fortunate purchase and historicalcost-based accounting.

The total effect of the problems briefly described above can be considerable. For example, a 5 per cent overstatement or understatement of costs can change an actual profit rate on sales or assets from 15 per cent to either 19 or 10 per cent. A 10 per cent overstatement or understatement of costs changes the "true" 15 per cent rate to either 24 or 7 per cent. ${ }^{63}$ These differences in the rates of return would swamp the numbers that distinguish a monopolistic from a competitive industry or a good from a bad investment.

\section{Conclusion: Total Costs and Benefits}

I believe that the weight of the arguments and data rather strongly supports the conclusion that the costs to society of government-required disclosure exceed the benefits that may be derived therefrom. This conclusion is particularly strong for the FTC's line-of-business report program. The cost to the corporations which would be required to report the data are high and the benefits are nonexistent at best and probably negative. The costs of the SEC-mandated disclosure are not as high, since the SEC generally permits corporations to follow their usual record keeping formats. Unlike the FTC's line-of-business program, it may have some positive benefits, on balance. Even so, these benefits do not seem to offset the costs.

It is clear that government-mandated corporate financial disclosure programs are being extended rather than reduced. The committee established to consider changes in the SEC's disclosure regulations ${ }^{64}$ has primarily recommended extensions of disclosure, though it has not recommended all that was proposed to it. The FTC's efforts to require large corporations to complete its forms are unrelenting, despite vigorous protests against its program. A question that should be considered, therefore, is, Why is government-required disclosure supported, despite its faults and costs? One answer to this question, I believe, can be found in the answer to another question: Who benefits from government-mandated disclosure? Another answer may be

63. See id. at Table 11 for a greater range of examples and for the formula on which these numbers are based.

64. See REPORT, supra note 4. 
found in an analysis of the public's belief in the necessity for government regulation.

One group of beneficiaries of government-mandated disclosure obviously consists of the government agencies and agents who administer the laws and use the data. Let me concede, at the outset, that many government employees are honest, hard working, and public spirited. Therefore, they naturally come to believe that the laws and regulations they administer are necessary, or at least desirable, for the efficient and equitable functioning of that part of society whose welfare is their charge. As they go about their jobs, they come to see that some scoundrels avoid the intent of the laws and regulations, or they find that the data they have are inadequate to answer some question. Hence they ask for improved and more extensive disclosure. But it is not conceptually possible for the disclosure ever to be adequate. As is discussed very briefly above, accounting numbers generally are poor measures of economic values and almost any system of accounting measurement can be misused by miscreants. Nevertheless, more data are demanded of corporations because more is almost always better than less to those who do not have to pay the cost of production.

A second group of beneficiaries consists of those people outside of government who use the data but who also, like the regulators, do not have to pay for it. SEC data are used by many (not all) securities analysts and by firms who process the data for sale to the public. It is not surprising, therefore, to find analysts among those who are most insistent on extending disclosure. For example, the Fixed Income Analysts Society has proposed to the SEC Advisory Committee on Corporate Disclosure that corporations be required to "send annual and quarterly reports to holders of registered corporate bonds, ... disclose in annual and quarterly reports ... information facilitating protection against defaults on payments of interest and of safety and market value of principal," and so forth. ${ }^{65}$ Their proposal seems curious, since these requirements could be written into the bond indenture agreements. One wonders, therefore, why bondholders have not asked for these data before, unless they had determined that the cost of the information (which they would pay for in reduced interest) was not worth the benefit. Analysts, however, work in the after-issue market. The required data would cost them nothing.

Accountants and lawyers are other groups that benefit from the disclosure required by the SEC. Both groups of professionals are in the business of selling their expertise, and the more extensive the regulations (up to a point), the greater the demand for their services. However, the benefits to them of great-

65. Fixed Income Analysts Society, Committee on Corporate Disclosure, Corporate Disclosure to Bond Investors and Analysts: A Report to the Securities and Exchange Commission and to the SEC's Advisory Committe on Corporate Disclosure 3-4 (1977). 
er disclosure are offset, in part, by the costs of greater legal liability and regulatory constraints. These costs have been imposed more on accountants than on lawyers (thus far at least). Perhaps that is one reason why the accountants have not been as supportive of extended SEC regulations as might have been expected.

Economists who specialize in industrial organization are an important group that hopes to benefit from the FTC's line-of-business data. These economists conduct studies of the relationships among market structure and profits, research and development expenditures, marketing, etc. The movement of corporations towards conglomerate form has deprived them of data on what they have been willing to describe as markets. Therefore, they look towards the FTC's line-of-business data as a plentiful source of grist for their mill. Since they neither have to pay the very high costs of producing these data nor even submit a grant application for the required financing, their interest is not surprising.

Finally, it is important to note that the public generally either (1) is unaware that the costs of required corporate disclosure are paid, ultimately, by consumers in the form of higher prices for goods and services and higher taxes; (2) overestimates the benefits and/or underestimates the costs; or (3) believes that the benefits outweigh the costs. The first factor is understandable. The costs of required disclosures are small relative to other costs of production. Therefore, even a doubling of disclosure costs that is reflected in prices probably would not be noticed by consumers, particularly in a period when inflation is so great and so variable. The second factor is also easily explained. The benefits from required disclosure are extolled by government officials, brokers, and analysts. Few voices are heard to the contrary. (Corporations do a very poor job in directing public attention to the effects of even more costly government programs.) The third factor, I believe, stems from a general feeling that the markets for goods, services, and capital essentially are not competitive and are plagued with shady dealings or worse. Furthermore, the economy is thought to be in need of control and regulation. These feelings may be residues from the experience of the Great Depression, when what was generally thought to be a competitive, free-enterprise, uncontrolled, and well-functioning economy apparently failed. From that time, increasing attention was paid to critics of the economy. The old beliefs were overthrown, generally with as little evidence as had supported their previous acceptance. But since the Second World War, a considerable body of analysis and empirical research has given us reason to question the assumption that the market economy had failed in the 1920's and early 1930's. Furthermore, forty years of experience with government regulation has provided evidence that its promise is not often achieved. If evidence is effective in altering beliefs, we have reason to hope for a change in the public's attitude towards the relative benefits of regulated versus unregulated enterprise. 